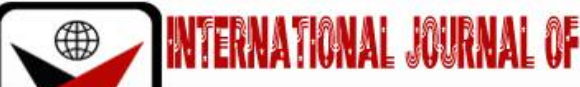

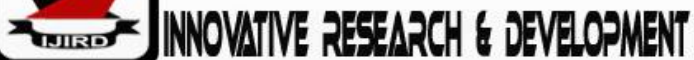

ISSN 2278 - 0211 (Online)

\section{Assessment of the Effectiveness of the 2014 Education Policy on Involving Parents in Decision Making In Ward Schools in Rukwa Region, Tanzania}

\author{
Dr. Ndasi Apolinary Kaswala \\ Lecturer, Archbishop Mihayo University College of Tabora (AMUCTA), Tanzania
}

\begin{abstract}
:
This study assessed the effectiveness of the 2014 Education Policy guidelines on involving parents in ward schools in Rukwa region, Tanzania. The 2014 Education Policy was introduced by the government of Tanzania with the aim of scaling up parents' roles and involvement in public schools so as to enhance elegitimation of decision-making and financial accountability therein. The policy required parents to take more part in major decisions and resolutions, monitor the policy implementation and initiate voluntary contributions needed in schools. It was the first-time parental involvement was amplified in Tanzania. This raised critical debate among the stakeholders on its implement ability triggered by persistent failure in implementing education policies on parental involvement and challenges of parents' participation in Rukwa region, Tanzania. The study employed concurrent parallel mixed methods research design. The sample comprised 364 participants and interview guides and questionnaires were used to collect data. Five experts from MWECAU faculty of education validated the instruments. Cronbach alpha test was used to determine the reliability of quantitative and qualitative data through confirmability, credibility, dependability and transferability. Descriptive and inferential statistics were used to analyse quantitative data whereas transcriptions, coding, categorizing themes and summarizing responses were employed for qualitative data. The study revealed that the policy guidelines were less effective in involving parents in schools as only a little was changed but worsening it to a large extent. The study recommends the government to review the approach to policy implementation to achieve its objectives.
\end{abstract}

Keywords: Decision making, parental involvement, policy effectiveness

\section{Introduction}

Parental involvement in schools through effective educational policies enhances the general effective administration and improvement of schools in different aspects (Rajabu, 2011; United Republic of Tanzania - URT, 2015 a). The aspects of school improvement include easy acquisition of resources in schools, upgrading of school buildings, students' discipline and high academic performance among others. Therefore, parents can enhance educational effectiveness if the policies provide space for their roles in the implementation decisions and resolutions in schools (Telli, 2014).According to Parkay, Anctil and Hass (2010), such policies, if effectively implemented, can make parents hold the management of schools accountable. The 2014 policy guidelines echoed this view by stipulating that parents in Tanzania should monitor the implementation of the fees free basic education policy in the country (URT, 2016 a).

Nevertheless, parental involvement in schools in Tanzania, through educational policies, has been a persistent challenge. It has adversely affected education quality due to its related effects such as students' indiscipline, truancy, dropout from school, shortage of teaching and learning material resources among others. Consequently, this has led to learners' poor academic achievement in the country (Maendaenda, 2010; URT - BEST, 2014; Nyandwi, 2014; Masue, 2014; URT, 2015). This has raised serious concerns among many stakeholders on the need to device and implement effective educational policies on parental participation in schools for enhancement of education in the country (Bernard, 2004; Focus, 2010; Magava, 2015, Kalolo, 2016).

Parental involvement in schools in Tanzania has evolved through several stages. The scope of our study covers the periods from pre-colonial education to the 2014 education policy, which was put in implementation in January 2016 (URT, 2016 a). Except for the indigenous education, the other stages of educational policies, from Koranic and missionary education through colonial era,up to the Policy of Education for Self-reliance and the1995 Education Policy,were less effective on involving parents in schools in Tanzania. This has been widely expressive in various literature (Omari, 1968; Kimambo \& Temu, 1969; Clatworhty, 1969, Lawuo, 1977; URT, 2001, Magava, 2015; Hakielimu 2017). Whether the 2014 Education Policy could make a difference was not yet clear by the time of conducting this study.

In the precolonial era, parents and other elders in the family and in community in Tanzania, like other parts of Africa, were central to the education of their children (Njoroge \& Bennaars, 1986; Owino, 2000). They had an active role in planning, teaching and evaluating the education of children to enable them fit well in society. It included instilling and 
preserving cultural values and sense of responsibility among members of a community. Farming, livestock keeping, iron works, basketry, herbal science, crafts and other specialized skills were learned by doing from parents and other elders (Datta, 1984; Seni, 2013). It was collective in its management and administration since all stakeholders were responsible for educating children and the youth. It was effective as its plans were successfully implemented and the objectives of society achieved (Nyerere, 1967; Bennaars, 1993).

With the introduction of Koranic and missionary education systems, the African indigenous education system dwindled. It included new curricula that was administered by foreign teachers (Scott, 1925; Nettelbeck, 1974). As the African parents and community members had no knowledge of the alien systems of education, they had to rely on foreign teachers who could manage the curricula. Additionally, the different agencies of Western and Islamic education had varied educational objectives which obstructed the African collective practice of involving parents in education besides dividing them (Kimambo \& Temu, 1969; Seni, 2013).

Consequently, the parents' roles changed from teaching and managing students to sending their children to formal schools and/or paying fees and other education costs (Kimambo \& Temu, 1969). Thus, the African collective responsibility and efficacy in education was replaced with professional individual teachers. This can be pointed out as the origin of parental alienation in schools in Tanzania and in Africa in general.

During colonial period, there were no expressive education policies on parental involvement. (Seni, 2013; Nettelbeck, 1974). Parents' roles were mainly to enrol their children in the schools and to pay fees and provide other education needs for their children; they were not involved in decision making in schools (Lawuo, 1977, Tarimo, 1996).

It can be concluded that the colonial education system did not encourage parental involvement among the Africans as it was meant to suit the capitalist economy. Clatworthy (1969) concluded that the British colonial education policy failed to match education to economy. Presumably it could succeed if it had involved African communities / parents in decision making. As a result, the people of Tanzania reacted against colonial and missionary education policies. They sought education that they were interested to partake in its management (Omari, 1968). This was one of the driving forces of nationalist movement in Tanganyika. Parents' concerns for limited access to the education of their children, plus the expenses of sending them to Uganda for primary and secondary schools, made them start their own schools, or even individual schools. The case of Ms Mary Ibrahim, who opened Mtoni School in Temeke, Dar es Salaam, is a concrete example of such initiatives. Later, the Tanganyika African Parents Association (TAPA) was formed in 1955. TAPA was officially registered as an organization in 1957 with objectives of providing education to all Tanganyika children; preserving the dignity, respect and unity of parents, consultation with the Ministry of Education and other decisionmaking bodies on children's education without any discrimination and establishing and running its own schools (THAKERS Ltd, 1965). In consequence, TAPA was extensively heralded by many parents in Tanganyika at its initial stage. It spread from Dar es Salaam to other regions in Tanganyika (Omari, 1968). TAPA built and managed many schools.

However, besides the registered achievements, TAPA had a number of limitations with regards to parents' roles. The association had inherent political interests from its onset. At other times, TAPA neglected parental representation and concentrated on TANU activities. It managed schools on behalf of TANU until in 1961 when they became officially registered as TAPA schools. Additionally, it was an association of some parents, who registered as members of the association but not all parents in the country. Subsequently the association lacked parental collective synergy. Therefore, the parents were not adequately coordinated and had no sufficient information in TAPA schools. In consequence, parents could not make informed decisions in this regard (Omari, 1968).

The period from independence (1961) up to the time before Arusha declaration in 1967, was the time the government took an upper hand indecision making in schools. The local authorities and school committees represented the local communities, especially in primary schools (Mwingira \& Pratt, 1967)while in secondary schools'parental representation was through the board of governors (Cameron \& Dodd 1970). Decision-making, resolutions and recommendations in education were issued by the government and its representatives (Hanzen and Hundsdörfer's 1982).

This practice failed due to lack of supporting system of the grassroots level including parents (Tarimo 1996; Magava, 2015). The education policy for self-reliance ended up with creation of a gap between parents and teachers to a point of enmity due to the government's sole control of education (Omari, 1968). Some teachers did not want to relate with parents as they had negative attitude towards parents' views and ideas. Therefore, parents' meetings were rarely held with teachers. The teachers' behaviour and superiority complex made parents to dislike them (p.20). Therefore, during the time of the implementation of the Arusha Declaration, parental involvement diminished and the policy did not achieve its objectives (Omari, 1968, Tarimo, 1996; Magava, 2015).

Following the world economic readjustment and economic crises in Tanzania in the 1970s and 80s, the country was forcedto make changes that included widening the horizon for stakeholders' involvement and legalizing ownership and management of private schools. The government's sole role in providing education ceased and parents and communities were expected to play a greater role in the running of schools (Tarimo, 1996; Seni, 2013).As a result, the government established secondary school governing boards (SGBs) through the education Act Number 25 of 1978 for the purpose of involving parents and communities in the governance of secondary schools (URT, 1978; 1995). In 1984, the government adopted cost sharing policy for public secondary schools. Parents paid fees and other students' costs and were to be represented in the school governing boards (, URT, 1995; Tarimo, 1996).

However, the policy failed to effectively involve parents (Makwinya and Komba, 2014; Raphael, 2008; Wilson, 2015). The legal framework was inhibitive of parental involvement (Buliro, 2014; Zahra, 2014; Masue, 2014; Mujora, 2014; Fanuel, 2015).The education policy failed due to inadequate involvement of the grassroots stakeholders including parents (URT, 2001; Mtolea, 2007). Most parents perceived the school governing boards as inadequate in representing them and even raised concerns on lack of democracy in the boards (Bernard, 2004; Focus, 2010; Khalfan, 2010; Kuleana, 
1999). Admittedly, the government of Tanzania acknowledged that the former education system had neglected some key stakeholders of education, including parents, and, therefore, committed itself to reform the system to involve them (URT, 1995). It further shows the need to involve parents in decision making in schools (URT, 2001).

This was followed by decentralization by devolution in 2004 in the Secondary Education Development Plan (SEDP), and the establishment of ward (community secondary) schools (URT, 2004). This was another government community/parents partnership in education. SEDP directed communities to construct school buildings up to lintel level and the government accomplished the finishing and employing of the teachers in the schools. Besides this laudable partnership that resulted in significant expansion of ward (community secondary) schools (URT, 2004), the schools performed poorly in quality as both parts seemed not to adequately play their roles (Makwinya and Komba, 2014). Team Review of PEDP I and SEDP I reported that the "top-down" directives in the education programmes in Tanzania undermined the competences and empowerment of school committees in the management and use of funds allocated to schools. This minimized the sense of ownership and creativity of school committees, whereby control of funds received were directly allocated to the specific activities (Munishi, 2014; URT, 2014).

Parents and other members of communities did not know what next after they built the schools. They did not know what was going on in the schools (Focus, 2010; Maendaenda, 2010). Therefore, the parents and communities were excluded from the management of the schools which they had participated in establishing.

More recent studies still reported on insufficient parental participation in decision making in schools (Fanuel, 2015, Kalolo, 2016). Additionally, decision making structure (school governing boards) has remained the same. This is one of the issues that inhibit parental participation in decision making in schools there by occasioning persistent concerns of parents and scholars (Bernard, 2004; Mtolea, 2007; Kalolo, 2016). Therefore, the government's commitment to improve parental involvement through the 1995 policy and decentralization by devolution in 2004 (PEDP and SEDP) did not decisively address the challenge of lack of parental participation. This is also featured in a research report by Mbelle (2008) that recommended more parental participation so as to improve education standards and management in primary schools in the country. Whether the current policy made positive changes was yet to be seen.

At the 2014 phase of education policy, the government came up with new and commendable approaches to parental involvement in schools. For the first time, parents were given room, not only to actively participate in the decisions and resolutions made in schools, but were also empowered to monitor the implementation of the fees free basic education policy. This created high expectations and interests among the education stakeholders in the country (URT, 2015, URT, 2016).The government was aware that education quality was influenced by varied factors ranging from curricula, human and material resources, leadership, management, evaluation and general school environment. It was aware also that the country faced a number of educational challenges that were related to these aspects and was therefore, committed to improvement of education in the country (URT, 2014).

Initially, the government of Tanzania, through the Ministry of Education, Science and Technology, released circular number 6 on $10^{\text {th }}$ December 2015 that guided the implementation of the education policy whose main focus was the aspect of parents' involvement in education matters. However, the circular created some confusion and misunderstanding as it was not specific on the areas in which parents were to participate in decision making and excluded other members of the community. Its communication was also more of a political than professional approach. In consequence its implementation was self-constraining (Siyame, 2016 b).

There were several cases that parents and other members of communities resisted to cooperate with the policy guidelines (Siyame, 2016 b; Ismail, 2017). A study by Hakielimu (2017) informed that teachers, members of school boards and school committees had not seen circular number 6 of 2015 by the time this research was conducted in 2016 . It was kept in school heads offices without disseminating it to the education stakeholders. This could be a leadership matteron the part of the school heads. It suggests that by then it was not well communicated. The study also unveiled that the concept of fees free education was not clear to most parents and that parents were ready to contribute but were not allowed by the circular (Hakielimu, 2017). This shows how controversial the document was. Kapinga (2016) emphasized on parental and community participation in financing the schools even though it was fees free education so as to assist the government's efforts of ensuring availability of adequate school facilities.

In consequence, the government issued circular number 3 on 25 May, 2016 clarifying the place of the community and parents' participation in decisions and resolutions made in schools (URT, 2016). This circular included other community members who were not covered in the former circular. To this effect, circular 3 is elaborate, clear and can be understood. Further clarifications have been made by the government with regards to parents' responsibilities in a fees free basic education policy besides the fact that circular 3 is clearly elaborated (Chawe, 2017). However, it was uncovered whether the policy was now clear to all parents.

The circular also empowers parents to monitor the implementation of fees free basic education policy of 2014, which aims at enhancing educational leadership, supervision and management that is relevant and accountable (URT, 2014) among others. However, it was not known whether parents knew clearly what was required of them and whether they were ready to implement this section of the circular. Even the directive on authorization of voluntary contributions for solving challenges in schools emphasises that community members should raise the challenges through legitimate school meetings and then school boards determine and endorse the proposed voluntary contributions (URT, 2016 c). This is an extension of parents' empowerment in participation in schools' decisions through local communities.

Literature indicated that Rukwa region faced a number of educational challenges that pertained to parents and the local community. They included the local community not valuing education, lack of formal education among most parents, lack of educational awareness, and lack of cooperation of parents with educators, among others (Mhegera, 2011; Nyandwi, 2014; Mshani, 2015; Siyame, 2016 a \& c; Yassin, 2017). The region had relativesmall number of community secondary 
schools (57 in 2014 and 70 in 2017), high percent shortage of furniture - students' chairs and desks (34.7\% and 33.4\%) respectively (BEST, 2014) and very high dropout rate of 9.3 (for government and private secondary schools) and the highest rate of $10.7 \%$ (only government schools) in the country (BEST, 2016).

Some parents colluded with their children to drop from schools and securedjobs as unskilled labourers in different economic sectors (Mhegera, 2011; Siyame, 2016 b). There were cases where parents and community members even assaulted teachers and declined to meet and discuss the matter contrary to the directive of ward education and executive officers (Yassin, 2017). Some other parents threatened teachers when they made follow up of their truant children besides not caring about their children's truancy (Mshani, 2015). The situation of Rukwa region carried the implication that successful implementation of the policy was uncertain. There was a need to assess its practicality or implementability. Assuming that the policy guidelines were being implemented in Rukwa region might fail the government to achieve its objective of including parents in making decisions and resolutions in the schools.

\subsection{Statement of the Problem}

Tanzania's education stakeholders have severally expressed concerns about education policies that have limited parents' roles in the management of public schools besides not being implemented appropriately (Kalolo, 2016; Makwinya and Komba, 2014, Magava, 2015). There have been also contrary findings on implementation of education policies on parental involvement in schools in Tanzania. Whereas scholars such as Salema(2009) and Fanuel (2015) reported high level of policy implementation on parents' involvement, other scholars like Makwinya and Komba(2014) and Magava (2015) reported in effective implementation of the same. Even after the launch of the 2014 education policy, through the 2016 guidelines on parental participation in schools, stakeholders were still debating the effectiveness of the policy (Kapinga, 2016; Hakielimu, 2017; Chawe, 2017). Above all, Rukwa region was facing exceptional challenges on parental involvement in schools (Mshani, 2015; Siyame, 2016; URT, 2016; Yassin, 2017). Whether the 2014 education policy could augment parents' involvement in the schools in Rukwa region, as per the guidelines, was unknown. The reviewed studies dealt with other aspects, not on policy effectiveness on involving parents in decision making in schools as per the 2014 education policy guidelines. Above all, there was limited literature on the area of policy effectiveness on parental involvement in schools in Rukwa region and in Tanzania in general.

This study, therefore, assessed the effectiveness of the 2014 Education Policy in involving parents in decision making ward secondary schools in Rukwa region, Tanzania.

\subsection{Research Question}

This study was guided by the following question:

- How effective is the 2014 Education Policy on involving parents in decision making in ward schools in Rukwa region?

\subsection{Research Hypotheses}

This study tested the following hypotheses:

- There is a significant difference in the mean rating scores of heads of schools on effectiveness of policy guidelines on improving parental involvement indecision making in ward schools in Rukwa region when compared with rural coastal and rural upland zones.

- There is a significant difference in teachers' mean scores on the policy guidelines' contribution to parental involvement in decision making in ward schools in Rukwa region based on education level, school location and work experience.

\subsection{Conceptual Framework}

Conceptual framework is an illustration or a symbol that represents a theoretical view. Punch (2009) views it as a representation of variables or main concepts (p.83). In our case it is conceptualization on the relationship between independent and dependent variables in terms of influence on one on the other. It symbolizes that parental participation in school decision making is determined by varied factors. In consequence, the factors determine the implementation of the policy. The following (figure 1) diagram summarizes the concept.

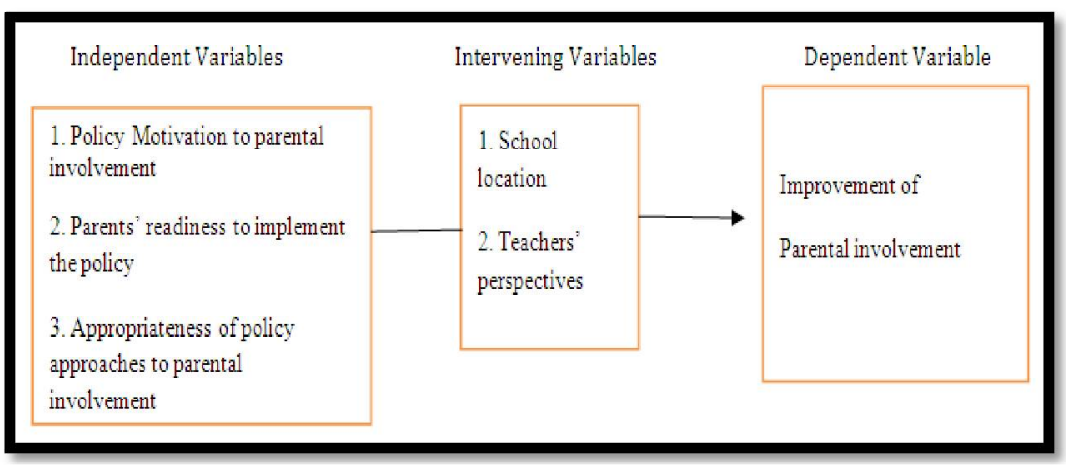

Figure 1: Conceptual Framework

Source: Adopted and Modified from Creswell (2014), Figure 3.1, P.89 
As the diagram indicates, the improvement of parents' involvement in decision making in schools depends on how the policy motivates them and makes them ready to implement it. The way the policy approaches are appropriate to parental involvement (as independent variables) determine the level of parental involvement (the dependent variable). These are determinants of how the policy was effective on improving parental involvement in the schools. Their effects were, therefore, measured in the questionnaires. School location and teachers' perspectives and characteristics (the school heads' and teachers' work experience in the region and education level) could affect their responses on the effectiveness of the policy, and subsequently affect the dependent variable. To this effect, they were determined in the hypotheses tests.

\section{Literature Review}

Parents can do a lot in schools if good planning and coordination is carried out by school administrators and other government authorities. If given an opportunity, and if they are committed to the education of their children, parents could significantly contribute to school improvement by their involvement in different school activities. When there are defined appropriate strategies to involve parents, it can make them work together with schools' heads and therefore enhance achievement of educational goals and objectives.

Even so, it is good to note that there cannot be one approach that can work a hundred per cent to involve parents' involvement in schools. Much as there are a flurry factors affecting parental involvement in schools, a single strategy may not work effectively to enhance their active participation in school matters in all contexts. A synergy of strategies is key to the successful parental involvement. Butsankom; Sirichuthi and Lammana (2016) have pointed out that diversifying approaches to parental involvement is needed for its effectiveness.

Scholars have suggested varied approaches to effective parental involvement in schools. They include, among many others, conducting studies on parents' proposals, involving the in decision making, establishing parents' units in schools, home visits and proper parent- school communication (Kabir \& Aktel, 2014).Other scholars have proposed formulating education policies that favour parental involvement and creating attractive school climate that is also responsive to parents' concerns (Tricia, Paul and Lewis, 2011; Rapp and Duncan, 2012).

Most of these strategies might work in the Tanzanian context depending on their application. As such, they are taken as hypotheses for their practicability to be seen in other areas, bearing in mind that most of them worked in Europe, North America and other part of the world and only a few in Africa. Moreover, participatory decision making is assumed to be the most effective approach as the case of Kitamburo School in Kilolo District - Iringa, Tanzania exemplifies (Ngalawa, Simmt, and Glanfield, 2015). Varied approaches have been proposed or recommended by scholars for effective parental involvement in schools. They are related to participatory decision making, putting in place elaborate means of involving them and accommodative legal framework to parents, among others. In their study, Kabir and Aktel (2014) pointed out parents' suggestions for improving their involvement in schools which included home visits, setting up parents' consultation programmes about their children's education, proper home-school communication, parents' gatherings in schools, and establishing a particular division for parents in schools. These might work in Tanzania to some extent. However, these might be hampered by other factors such as geographical areas, number of teachers and their motivation and financial capacity among others. Investigating on various techniques to attract parents is crucial. Neil, Alexandra and Ann (2015) explored the possibility of using the "structured conversations with parents" model to improve parental participation in schools in England. The purpose was to encourage parents of learners with special educational needs and disabilities (SEND). The findings of the study showed that structured conversations with parents proved to be the most appropriate medium of parents' communication to education authorities. Though this model might be effective in new environments, the study did not focus directly on policy requirements for parents. One of the most effective approaches is to establish teacher-parent relationship that will motivate parents to participate in the running of schools. Ensuring parental participation through purposive encouragement and appreciating their role can also motivate parents to take part in school governance. Different avenues of involving parents need to be exploited. In their study, Butsankom; Sirichuthi and Lammana (2016) found that, in Thailand, promoting participatory decision making, building cooperation between teachers and parents was an effective model of education management. However, the study dealt with general parental involvement besides including decision making aspect. It was also a case study for one school that cannot be generalised to other cases. It is uncertain whether it can be applied to Tanzanian conditions where parents' roles in decision making are provided by education policy.

If parents have knowledge and confidence, they can use them to influence schools in different ways. Feuerstein (2015) examined the strategies applied to motivate the parents to intervene in the operation of the failing schools through petition in the United States of America. Qualitative design was used to analyse the media texts generated by different organizations in the policies. They included the American Legislative Exchange Council, American Enterprise Institute and Parent Revolution. The study findings indicated that metaphors, exemplars, catch-phrases and appeals to principles were the most frequently used framing devices. They based on appeals to principles, root causes and consequences. These imply that knowledge power was used by parents to intervene in failing schools based on analyzed root causes and consequences and they appealed to models, exemplars and metaphors. The analyzed approaches used by parents to intervene in their children's education were appropriate and effective to achieve their educational objectives. However, one is not sure whether such techniques and ability that were used by American parents are applicable to parents in Tanzania. It is also not clear whether parents were officially empowered to hold school administrators accountable for not complying with educational policy guidelines. The socio - cultural aspects of different environment also constituted knowledge gap for our research.

Paying attention to parents' perspectives is necessary to win their support as social capital in education. Denise (2013) studied parents' perception of school leaders as it relates to parents' engagement and the African American 
students in U.S.A. The research objective was to determine parents' perception on the quality of their children's education and the quality of communication they received from the children's school. Purposive sampling was used to select parents and a questionnaire was the instrument used for data collection. The study found that parents were satisfied with the quality of education provided to their children and the communication made to the parents by the schools. They subsequently felt that they were viewed as partners. It was thus possible for them to participate in school decision making committees much as they were satisfied with school administration, though did not feel as equal partners. This report is important on the part of what the schools were doing but not what parents were to do. All the more, it was delimited on communication of school to parents, and left out partnership in decision making. Parents' role and their views on the same were not covered by this study, nor was the communication model clearly stated. No specific educational policy was also addressed.

Establishing relevant parental involvement frameworks can enhance implementation of education plans. Supportive national culture and polices can lead to effective parental involvement in schools. Tricia, Paul and Lewis (2011) compared the levels of parental participation in public school governance and in decision making in the U.S.A. and in the post-apartheid South Africa. The study revealed that parents in South Africa were more involved in school governance and in decision making than parents in the United States of America. South African policy encouraged parents through School Act of 1996. The parents in the U.S.A. were less involved for the reasons that are not reported by the study. Hence a legal framework can be supportive of parental involvement when it is clearly formulated and well communicated. The experience of the apartheid policy might have influenced parents in South Africa to be more active in parental involvement as they had struggled for democracy for a long time. Scholars concur with the views that policies need to be sensitive to parents' interests and views to attract their involvement. Rapp \& Duncan (2012) have insisted that school leaders should establish effective policies that ensure parents' involvement as a way of encouraging of partnering with parents and other stake holders. The policy should include respect and recognition of parents' potentials, welcoming school environment, an effective communication to parents' familiarity with community leaders, and educating parents on the importance of education and their roles as parents. These need testing to see if they can apply in the situation of policy requirements in Tanzania.

Making parents aware of what is required of them enhances their involvement in schools. In most cases, parents are aware of their financial obligations because they are normally made clear by school's management. This makes parents to cooperate with schools by playing their financial roles effectively in schools. Mbaraka (2015) assessed parents' degree of financial contribution for secondary education in Tanzania through a comparative study between community and private secondary schools in Ilala Municipality, Dar es Salaam. The researcher employed concurrent mixed approach with a sample that comprised 12 school heads, 102 teachers, 360 parents and 360 students. Interview guide, questionnaire and observation schedule were used to collect data. The study revealed, among others, that majority of the parents ( $95 \%$ ) were aware of their financial obligation. However, one is not sure if financial obligations were passed in meetings that involved parents. It is also unclear whether financial obligations were based on the national or school policies. Hence, parental participation in decision making is not reported. To sum up, the most effective approaches to parental involvement in schools include participatory styles (Butsankom, Sirichuthi and Lammana, 2016; Ngalawa, Simmt and Glanfiel, 2015), proper parent - school communication and creating parents' awareness (Kabir \& Aktel, 2014; Feuerstein, 2015), formulating policies that favour parental involvement (Tricia, Paul, and Lewis, 2011), creating attractive school climate and being attentive to parents' perspectives (Denise, 2013). As circular 3 and procedure for voluntary contribution empower parents in Tanzania (URT, 2016 b \& c), their implementation remains to be verified as none of these studies provides the evidence for their functioning. This constituted a knowledge gap to be filled by this study.

\section{Methodology}

Concurrent parallel mixed research design was employed as both qualitative and quantitative data was collected and compared at interpretation and conclusion, though the two types of data were analysed separately (Creswell, 2014, p. 269). The design enhanced deeper understanding of the answers to the research problem. This design has been advocated by a number of scholars that it strengthens the study by addressing the weakness of individual designs (Creswell, 2009; Punch, 2009, p.290; Ary, Jacobs, and Sorensen, 2010, pp. 23 \& 25). Therefore, it improves validity and reliability of the study through data triangulation. The target population in this study included the district education officers (DSEOs), ward education coordinators (WEOs) heads of secondary schools (HoSSs), chairpersons of school governing boards (CSGBs) in community secondary schools, teachers in management teams (TMTs) in schools and parents having children in the schools and were responsible for their education and all ward schools in Rukwa region.

The study selected 40 heads out of 70 HoSSs in the region and 40 teachers from among 280 TMTs. The other participants included one WEO and one CSGB in each school/ward plus one DSEO from each of the four districts. The study applied probability and non-probability sampling techniques. Questionnaires and interview guides were used for data collection. The instruments were pilot tested to 4 HoSSs, 4 CSGBs, 4 WEOs and 16 TMTs in four ward schools that were excluded from the sample of the main study. It was done also to 30 parents. It enabled the researchers to check for language clarity, relevance to research questions, understand ability, and spacing for responses. Pilot testing the interview guide was done to 4 HoSSs. It tested practicality, time needed for interview, communication ability of participants and relevance of responses to the research questions. The researchers made relevant corrections of the weaknesses identified during pilot testing of both instruments and made needed changes on the instruments for improving their validity.

The qualitative data was analysed by transcriptions, identifying and categorizing themes and summarizations. Descriptive and inferential statistics were used to analyse quantitative data. Reliability for quantitative data was established by Cronbach alpha and qualitative data through confirm ability, credibility, dependability and transferability. 


\section{Findings and Discussion}

The study research question sought to measure the effectiveness of the policy directives on involving parents in schools. The underlining assumption was that effective policy guidelines would augment parental involvement and achieve the government's objectives of improving legitimation of decision making, accountability and shared purpose in managing the schools. This section comprises the seven aspects which are: parental involvement before the policy guidelines; whether the guidelines improved the involvement of parents; levels of effectiveness of the guidelines; parents' readiness to report malpractices in fees free education; reporting modality of malpractices; the authorities that the parents would report to and hypotheses testing. The information for measuring the effectiveness of the policy guidelines on parental involvement was obtained from school heads, DSEOs, WEOs, chairpersons of school governing boards and parents.

\subsection{Parental Involvement before Implementing the Policy Guidelines}

The aspect of parental involvement before implementing the policy guidelines was measured by the five-point ranking scale of: very low $=1$; low $=2$; average $=3$; high $=4$ and very high $=5$ plus the open-ended item that asked the reasons for the rating. The data that was collected from the questionnaire of the heads of schools revealed the following as summarized and presented in Table 1.

\begin{tabular}{|c|c|c|}
\hline Response & Frequency & Percentage \\
\hline Very Low & 00 & 0.0 \\
Low & 12 & 37.5 \\
Average & 00 & 0.0 \\
\hline High & 20 & 62.5 \\
Very High & 00 & 0.0 \\
\hline Total & 32 & 100.0 \\
\hline
\end{tabular}

Table 1: Level of Parental Involvement before Implementing the Policy Guidelines

The results in Table 1 disclosed that more than a third percent (37.5\%) of school heads indicated parental level of involvement was low before the implementation of the policy guidelines and about two thirds percent (62.5\%) indicated it was high. The situation before the release of the policy guidelines seems to be better in relation to parental involvement in most schools and was low in few schools. The findings imply that the policy guidelines impacted positively on parental involvement by one third but with negative changes by about two thirds. It means that the policy brought more challenges in most schools and made positive impacts in few schools. In this regard the guidelines were not effective but proved to be more challenging.

\subsection{Whether the Guidelines Improved Parental Involvement in Schools}

The researchers examined whether there was some improvement in parental involvement in schools after the implementation the 2014 policy guidelines. The data were collected from DSEOs, WEOs, heads of schools, and the TMTs. The findings from school heads' responses on questionnaires on whether the policy had improved parental involvement are presented in Table 2.

\begin{tabular}{|c|c|c|}
\hline Response & Frequency & Percentage \\
\hline Even worse & 16 & 50.0 \\
\hline No change & 7 & 21.9 \\
\hline Better & 9 & 28.1 \\
\hline Total & 32 & 100.0 \\
\hline
\end{tabular}

Table 2: Hosss' Responses on Improving Parents' Involvement

As per the results in Table 2, half of the participants (50\%) showed that the implementation of the policy guidelines worsened parental involvement in the management of the schools and less than quarter percent (21.9\%) indicated that the guidelines made no any change. More than a quarter percent (28.1\%) indicated that the guidelines improved parental involvement in the management of the schools. In this regard the policy guidelines were ineffective.

Some heads of schools, who indicated the policy guidelines worsened the situation, revealed that the parents did not understand the policy well and that they were no longer making contributions in schools. They added that parents no longer cared about their children in the schools and were uninterested in attending parents - school meetings. One head reported in the questionnaire: "Instead of enhancing positive parents' involvement in pushing education matters together, the policy has isolated them and made many academic, environmental and school buildings even worse".

Similarly, another school head stated in the questionnaire as: "Parents think that the circular number 3 of 2016 is guiding the government to be responsible for everything. What parents are doing now is just to buy school uniforms and exercise books".

Yet another head wrote:"About 98\% of the parents nowadays, after implementing the 2014 education policy guidelines, are not participating effectively since they depend on each and every thing from the central government for the development and growth of the ward school". During the interview, some school heads said that most parents did not assume their responsibilities any more. One head of school said: "The parents are made to believe by politicians that the government will do everything for their children's education". 
Supporting this view in the interview, one DSEO said that parents' pace of being involved in the schools had slowed down and that the parents believed that the teachers could do everything in the schools on their behalf. Some heads of schools indicated that there was no change on parental involvement and explained that the parents were still reluctant in matters of education in the schools since they were even misled by politicians. They added that parents did not value education and their level of awareness on matters of education was still low. During the interview, one head of school said:

Most parents do not understand the importance of education. They just send their children to school in fear of the government but they are irresponsible in many aspects of their roles such as making contributions for food, buying school uniforms and providing pocket money for their children.

Another head responded:"No changes because the parents do not make follow up of their Children's performance at our school and do not help teachers to contain truancy".

However, some heads of schools indicated improvement on parental involvement. They gave reasons that the parents had become part of school planning team and so they were more involved. Some explained that parents had become involved in schools and even the number of students' enrolment had increased. Hence, their involvement was to a large extent significant. To support this observation, one head of school had this to say: "It is better because parents have become part of the planning team for development of our school and so they get involved in the decision making on what should be done for proper school development". Correspondingly, another school head said: “... Because parents are participating in their meetings to the maximum level these days".

WEOs were asked to indicate whether parental involvement became better after the implementation of the policy guidelines. This sought to determine policy effectiveness on parental involvement. The yes and no questionnaire items were used to collect the data. It was revealed that $8(30.8 \%)$ WEOs indicated that parental involvement became better after the implementation of the policy guidelines. 17 (65.4\%) responded that it did not improve it. Some WEOs gave the reasons for indicating better parents' involvement that included increased parental attendance in meetings, participation in solving students' discipline issues, and more parents enrolled their children in schools compared to the past experience.

In this regard, one WEO stated:"It is better because now the parents know that the school is theirs and they have understood the importance of education in the society". Similarly, another WEO wrote: "They have contributed in the development of school infrastructure and some parents have participated in different ways in combatting absenteeism and dropout among the students".

Some other WEOs, who reported that the policy did not improve parents' involvement gave various reasons including parents' misunderstanding the meaning of fees free education, making contributions voluntary, parents not willing to take part in solving school problems and effects of fees free education. One WEO wrote as: "Voluntary contribution has led to confusion to a certain extent compared to previous tome as parents think they are no longer responsible for anything relating to school contribution, believing that the government is responsible for everything".

Another WEO wrote:"Before circular 3 of 2016, all the school infrastructure was done by involvement of parents. But after the circular, no any infrastructure is implemented by parents, even the desks. This is because contributions are voluntary".

The teachers in school management teams were asked a similar question, requiring them to indicate, on yes/no items, whether the policy guidelines contributed to more parental involvement in decision making in the schools. 9 $(27 / 3 \%)$ TMTs indicated that the policy guidelines contributed to more parental involvement in decision making in the schools but $24(72.7 \%)$ indicated that they did not make such a contribution. The results are similar to those from HoSSs and WEOs.

Based on the WEOs and HoSSs'statistics, therefore, the guidelines were to a large extent ineffective as more than half percent indicated that the guidelines did not improve parental involvement in school issues. These findings concur with those by Orotho and Adan (2015) which revealed that few parents were uninvolved in the implementation of free secondary education policy in Kenya as they declined to honour their obligations and negatively affected the implementation of the policy. The findings are also in agreement with Oyeniran (2017) who uncovered that parents were passive in the effort to involve them in the schools since basic education was free in the Ivory Coast.

However, the results are contrary to the findings by Leos-Urbel (2016), who reported that fees free education scaled up parental involvement in schools. They are contrary also to the findings by Ngalawa, Simmt and Glanfield (2015) that revealed parents' high involvement at Kitamburo primary school in Kilolo district in Iringa, Tanzania due to participatory decision making. Probably the issue of the parents not valuing education in Rukwa region and political influences counted on this difference as pointed out by teachers and heads of schools among other factors.

These findings are divergent also from Hakielimu (2016) report that showed that parents were no longer involved in schools completely. In this view, the policy regulations made some improvement on involving parents. The results also imply that the approach of the fees free education policy, through the guidelines, diminished parental involvement in most schools but improved it in few schools. This variation could be attributed to school leadership styles, level of awareness of local community or political influence as prior reported.

The implementation of the guidelines was practically ineffective in general. Besides, the guidelines were relevant theoretically as per the participants' reports. There is need, therefore, to align the theoretical and practical aspects of the education policy. The challenges of political influence and parents' low value of education featured throughout the responses of most of the participants. These variant results further confirm what had been reported in research question one that the policy was effective in some areas but less effective in some others. 


\subsection{The Level of Effectiveness of the Policy Guidelines}

The researchers sought to measure the level of policy effectiveness on involving parents in decision making in the secondary schools in the region. The data were obtained from the responses on questionnaires of WEOs and the interview schedule for DSEOs. The WEOs rating of the effectiveness of policy guidelines on the questionnaire are presented in Table 3.

\begin{tabular}{|c|c|c|}
\hline Response & Frequency & Percentage \\
\hline less effective & 8 & 32.0 \\
\hline $\begin{array}{c}\text { somehow } \\
\text { effective }\end{array}$ & 5 & 20 \\
\hline not sure & 2 & 8.0 \\
\hline effective & 8 & 32.0 \\
\hline very effective & 2 & 8.0 \\
\hline Total & 25 & 100.0 \\
\hline
\end{tabular}

Results in Table 3 revealed that 8 (32\%) WEOs rated the guidelines as less effective and the same proportion as effective. $5(20 \%)$ WEOs rated them as being somehow effective. $2(8 \%)$ of WEOs were not sure and the same proportion rated the guidelines as being very effective.

Some said the policy guidelines were less effective because parents did not understand them well. Others reported that making contributions voluntary made parents relax in contribution to education matters and that the politicians made them less effective as there were many problems in the schools. Even the implementation of the policy was not consistent as it was characterised by fluctuations. One WEO whose views corresponded with this finding wrote: "They are less effective because of the orders from the top authorities. Formerly parental participation in decision making at our school was very effective but now parents have been discouraged".

The others said that they were somehow effective as they led to more enrolment of children in schools and that most parents were attending meetings, parents perceived schools to be their institutions, they had made a link between schools, parents and board members gave some contributions for school development and that they had minimized school dropout.

On this finding, one WEO wrote, "...because of large number of students and reducing school dropout at a very large extent".

Some other WEOs rated the guidelines as effective and very effective for the reason that they made parents to actively take part in meetings and in implementing the resolutions. Some WEOs gave reasoned that the guidelines had made parents contribute to construction of school buildings and buying of school equipment. One WEO reported: "The policy guidelines have made high achievement due to high parental involvement in decision making and have led to improved and increased classrooms and other school buildings and facilities".

Three (3) DSEOs rated the policy, during interview, as somehow effective and one DSEO rated it as effective. 3 DSEOs ranked the policy on improving parental involvement at medium extent and 1 DSEO ranked it at large extent. The three DSEOs gave the reason that it worked at different levels in different environments while one DSEO said that it had changed and improved parental involvement in schools in general.

All the four DSEOs explained that the government's objective of empowering parents in running the schools was to enhance wider participation in the exercise so as to effect efficacy of the education management and collective responsibility. They explained that parents were part of the wider community that owned the schools and so they were responsible as the owners of the institutions. They added that amplifying parental involvement was for ensuring legitimate decision making in the schools as well as enforce cost sharing in a fees free education policy.

Based on the findings, one may reason that the effectiveness of the policy guidelines was low and a challenge as rating and ranking by participants indicated. Some saw it as effective, others less effective or very effective. The medium level of effectiveness means also the average achievement of the government objectives. The education officers (WEOs and DSEOs) must have responded based on their experience in their offices. The effectiveness of the policy guidelines varied based on the participants' experience. Probably, the local community, work experience and individual personal variables accounted for these variations.

Variations in levels of effectiveness refer also to variations in the levels of the involvement of the parents. It can be logically concluded that the effectiveness of the education policy guidelines depended on the prevailing situation in schools and the local community. The factors for the variations should be addressed for making homogeneous parental involvement so as to achieve the government objectives in a fees free education policy in Rukwa region.

The findings echo those by Lesley (2016) whose report indicated ineffective implementation of policy on involving parents. Similar findings were reported by Mualuko and Limukii (2012) that the fees free education policy was ineffective in involving parents in schools in Kenya. The same apply to Tricia, Paul and Lewis (2011) whose study reported that the education policies on involving parents were ineffective in the U.S.A. The findings are, however, contrary to effective policies on involving parents in countries such as South Africa (Tricia, Paul and Lewis 2011); school-based policy in Kitamburo primary school - Kilolo, Tanzania (Ngalawa et al., 2015) and communication with school policy in England (Neil, Alexandra and Ann, 2015). These cases can serve as models for formulating and implementing educational 
policies on parental involvement in our time. In a special way, Kitamburo primary school, which is also in Tanzania, can be the best example.

\subsection{Parents' Readiness to Report Malpractices in Fees Free Education Policy}

The parents' readiness to implement the directive of monitoring and reporting the malpractices in implementing the fees free basic education policy was another aspect of the focus of the study on the effectiveness of the policy guidelines. The parents were asked to indicate, in the questionnaire, whether they were ready to report malpractices in the implementation of the fees-free education in schools. A three-point scale of ready, not sure and not ready was used to generate the data on parents' questionnaire. The results are summarized in Table 4.

\begin{tabular}{|c|c|c|}
\hline Response & Frequency & Percentage \\
\hline ready & 111 & 63.43 \\
\hline not ready & 21 & 12.0 \\
\hline not sure & 43 & 24.57 \\
\hline Total & 175 & 100.0 \\
\hline
\end{tabular}

Table 4: Parents' Responses on Their Readiness to Report Policy Malpractices

Findings in Table 4showed that 111 (63.43\%) parents indicated that they were ready to report and to reprimand the malpractices in implementing the guidelines, $21(12 \%)$ were not ready and $43(24.57 \%)$ were not sure. The parents who were ready to implement the aspect in the guidelines explained that the policy had assisted the children of poor parents to access education and that it was their responsibility to hold schools accountable lest their children got troubles in schools. They explained further that they had to implement the education policy because it was the basis for the development at their school as demonstrated by one parent's declaration, "Niko tayari kwa sababu ndiyo chanzo cha maendeleo katika shule yetu"(which in English translates as ready because it is the source (basis) of the development at our school).

Those parents who said that they were not ready reasoned that the guidelines were directives by the top government authorities and so they could not correct them. Some said that they felt they could get into conflict with teachers and their fellow parents. Some felt that the fees free education was an important favour and so they could not reprimand and report the malpractices. This is clearly illustrated by parent who said: "Hapana kwa sababu wameturahisishia sisi wazazi wenye kipato cha chini kuweza kusomesha watoto" (I am not ready because they have simplified (made easy) for us parents with low income to afford education costs for our children).

These findings are contrary to the report by Redempta and Mwebi (2016) that showed that parents could even go against the education policy of extra tuitions as they were convinced that it was not beneficial to their children. While such parents in Tanzania felt privileged and were suggestible to the same, parents in Kenya evaluated the privilege of banning extra tuition to reduce the costs, among others, as a non-useful privilege and resisted it in favour of the banned exercise. This could result from parents' awareness and their level of education (Mahmoud, 2018).

However, some parents who were not sure to implement the guidelines argued that they did not understand the policy and so they could not detect the malpractices. Some explained that the policy guidelines had so many weaknesses and regular changes such that one was not sure of their implementation. One parent reported in the questionnaire: "kwa sababu maelekezo ya waraka namba 3 wa mwaka 2016 bado sijayafahamu". (Because I have not known the guidelines of circular number 3 of 2016). These findings match with the responses from two DSEOs who remarked that the policy had divided parents into the willing and ready and the unwilling and unreadyones to be involved in decision making in the schools. These results concur with some studies such as Lesley (2016), Mualuko and Limukii (2012), Matshe (2014) and Nyandwi (2014) that have pointed out that parents could not be involved in schools due to their lack of knowledge on the education policies. They concur with Mbugua and Rarieya (2014) and Lesley (2016) whose results revealed that parental involvement in educational policies were determined by their knowledge level of the same.

\subsection{The Mode of Reporting Malpractices by Parents}

The researchers explored parents' opinions and experiences on the means of communication when reporting and reprimanding the malpractices in the implementation of the fees-free basic education. The effective communication was considered to be important element in executing their roles. The mode of reporting included the use of phones, visiting schools, making use of meeting opportunities, writing letters, through students or did not know. Findings from parents' questionnaires are presented in Table 5.

\begin{tabular}{|c|c|c|}
\hline Response & Frequency & Percentage \\
\hline Phone & 5 & 3.27 \\
\hline Visiting schools/offices & 69 & 45.1 \\
\hline In meetings & 63 & 41.18 \\
\hline Letters & 13 & 8.5 \\
\hline Via students & 1 & 0.65 \\
\hline Do not know & 2 & 1.31 \\
\hline Total & 153 & 100.0 \\
\hline
\end{tabular}

Table 5: Parents' Responses on Reporting Mode of Malpractices 
The results in Table 5 revealed that less than a half percent (45.1\%) of participants opted to report malpractices through visiting either schools or officers responsible for the issues. More than a third percent (41.18\%) reported or would report in meetings, $13(8.5 \%)$ through letters, $5(3.27 \%)$ through phones. $2(1.31 \%)$ parents did not know the modality of reporting the malpractices and 1 parent $(0.65 \%)$ saw it fit to do it through students.

Most parents found reporting through visiting the offices with authorities as the most appropriate models of reporting the malpractices. This implies that the aspect of the guidelines was practical to parents. The parents had varied channels of communication with regards to reporting malpractices in the free basic education policy.

\subsection{Authorities to Who Parents Would Report the Malpractices}

The researchers sought to find out the authorities, parents reported to or would report the malpractices in implementing fees free education policy in Rukwa region. The information on this aspect were obtained from parents and from the DSEOs. Table 6 presents the summary of results of responses from the parents in the questionnaire.

\begin{tabular}{|c|c|c|}
\hline & Frequency & Percent \\
\hline Village authorities & 11 & 6.21 \\
\hline Councillor/MP & 19 & 10.73 \\
\hline DC/DED/RC & 14 & 7.91 \\
\hline Heads of schools & 24 & 13.56 \\
\hline WEO/WAS & 21 & 11.86 \\
\hline Do not know where to report & 23 & 12.99 \\
\hline CSGB & 19 & 10.73 \\
\hline Education Officer & 36 & 20.34 \\
\hline Chairperson of school committee & 10 & 5.5 \\
\hline Total & 177 & 100.0 \\
\hline
\end{tabular}

Table 6: Parents' Responses on Authorities to Report Malpractices

Findings in Table 6 exposed that $11(6.21 \%)$ parents reported or would report to village authorities, $19(10.73 \%)$ to councillors and members of parliament, 14 (7.91\%) to DCs, DEDs and RC, 24 (13.56\%) to heads of schools, 21 (11.86\%) to WEOs and Ward Administrative Secretaries(Was), 23 (12.99\%) did not know where to report, 19 (10.73\%) to CSGBs, $36(20.34 \%)$ to education officers, and $10(5.5 \%)$ to chairpersons of school committees. The participants identified the education officers, to whom they could report, from ward to the regional levels (WEO, DSEO and REO).

During the interview with the DSEOs, all the four confirmed that parents were free to report anywhere. However, one DSEO recommended that they should start at lower levels such as at the village and ward authorities' offices. This aspect implies that parents had wide horizon for reporting the malpractices in the schools. The parents implemented this aspect of the policy appropriately as the authorities they reported to were relevant and reachable. It was also easy to report in terms of authorities as the officials in the respective offices were available in close range to parents in all areas in the region, just like in other regions. It is because the government stats at street level.

\section{Testing Hypotheses}

\subsection{Independent Samples $t$ - Test}

The researcher examined whether there were differences in the mean scores of school's heads on whether the policy improved parental involvement in the schools based on two zones of coastal and uplands in the rural schools. Independent samples $\mathrm{t}$ - test was conducted. The null hypothesis states as; "There is no significant difference in the mean rating scores of heads of schools on effectiveness of policy guidelines on improving parental involvement in decision making in ward schools in Rukwa region when compared by rural coastal and rural upland zones". The results are presented in Table 7. 


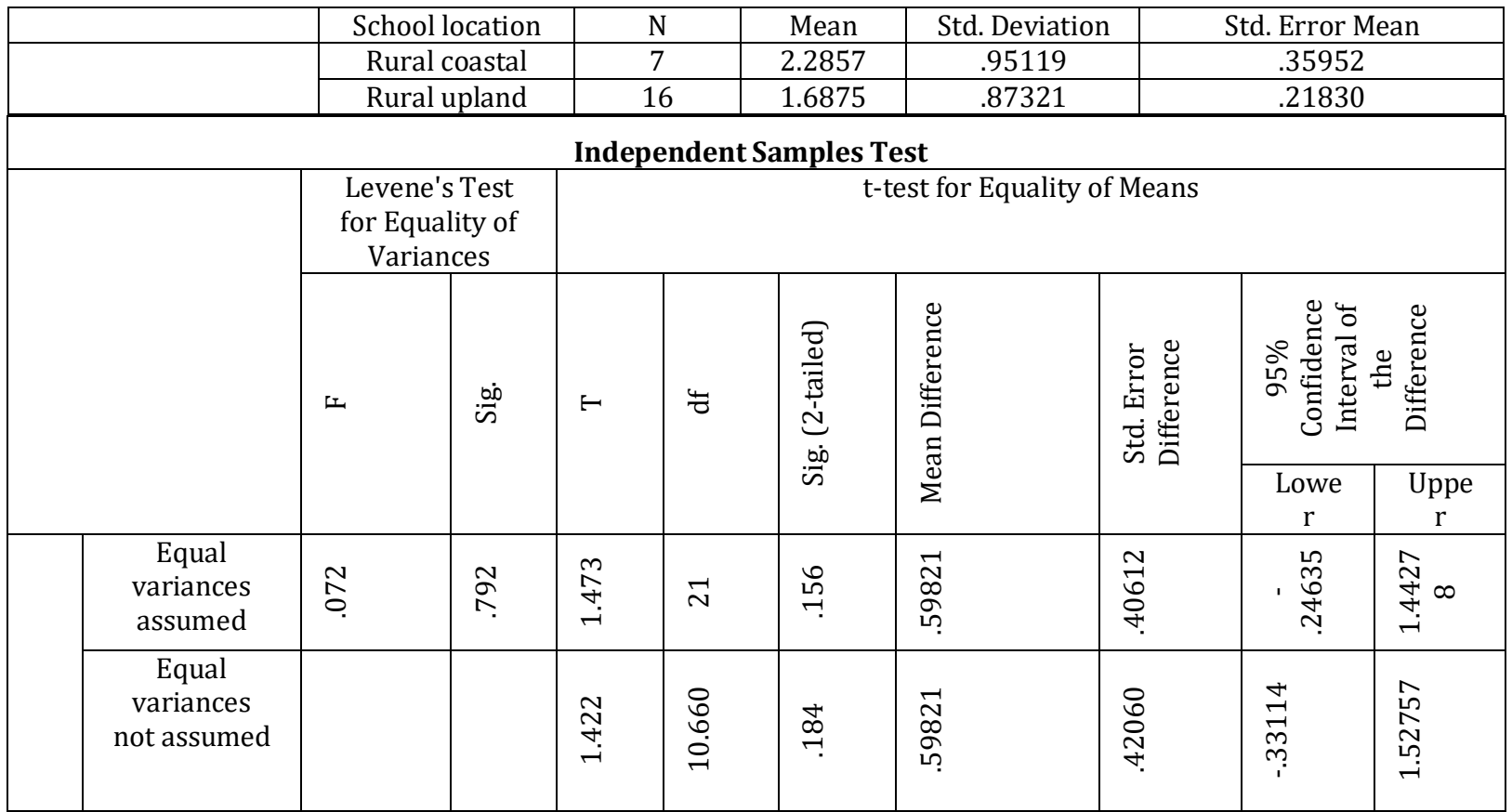

Table 7: T - Test Results on Effectiveness of the Policy on Improving Parental Involvement

The test results in Table 7 revealed no significant difference in the mean scores of the heads in rural coastal schools $(M=2.29, S D=.95)$ and in rural upland schools $(M=1.69, S D=.89), t(21)=1.47, p=.16$. This $p$ value of .16 is greater than .05 level of significance. The researchers failed to reject the null hypothesis and concluded that there was no significant difference in the mean rating scores of heads of schools on effectiveness of policy guidelines on improving parental involvement in decision making in ward schools in Rukwa region when compared by rural coastal and rural upland zones. Findings still confirmed that the school location and its respective local community had no significant different effects on the policy effectiveness in the context of implementation. It means the policy effectiveness was seen at similar level by participants regardless their working areas. Thus, the factor of school location did not significantly influence the scores of participants differently. Therefore, one can confidently reason that policy guidelines and political related variable influences could have been the major factors for the level of implementation of the fees free education policy in Rukwa region as earlier noted.

\subsection{Three Way Anova}

The study made further hypothesis test to find out whether teachers' experience of management teams, geographical area and level of education had significant main effects on their scores on policy contribution to more parental involvement. The null hypothesis stated as: “There is neither significant difference in teachers' mean scores on the policy guidelines contribution to more parental involvement in decision making in ward schools in Rukwa region based on education level, school location and work experience and no significant combined effect of the three independent variables". Table 8 presents a summary of findings.

\begin{tabular}{|c|c|c|c|c|c|}
\hline \multicolumn{7}{|c|}{ Tests of Between-Subjects Effects } \\
\hline \multicolumn{7}{|c|}{ Dependent Variable: responses } \\
\hline & $\begin{array}{c}\text { Type III Sum of } \\
\text { Squares }\end{array}$ & $\mathrm{df}$ & Mean Square & $\mathrm{F}$ & Sig. \\
\hline Source & $.599 \mathrm{a}$ & 7 & .086 & .360 & .917 \\
\hline Corrected Model & 33.542 & 1 & 33.542 & 141.027 & .000 \\
\hline Intercept & .014 & 1 & .014 & .058 & .812 \\
\hline location & .008 & 1 & .008 & .034 & .855 \\
\hline experience & .285 & 2 & .142 & .598 & .557 \\
\hline education & .009 & 1 & .009 & .038 & .847 \\
\hline location *xperience & .030 & 1 & .030 & .127 & .725 \\
\hline location* education & .088 & 1 & .088 & .371 & .548 \\
\hline experience* education & .000 & 0 &. &. &. \\
\hline location * experience * education & 5.946 & 25 & .238 & & \\
\hline error & 105.000 & 33 & & & \\
\hline
\end{tabular}

Table 8: Three Way Anova Results of Teachers'Scores on

Policy Contribution to More Parental Involvement

Results in Table 8 indicate that there was no significant effect of teachers' education level, $\mathrm{F}(1,25),=.598, \mathrm{p}=.55$. There was no significant effect of school location, $F(1,25)=.058, p=.812$. There wasno significant effect of work 
experience, $\mathrm{F}(1,25),=.034, \mathrm{p}=.855$. The findings indicated no significant interaction of school location and work experience $\mathrm{F}(1,25)=.038, \mathrm{p}=847$; no significant interaction of school location and education level, $\mathrm{F}(1,25)=.127, \mathrm{p}=$ .725; and no significant interaction of work experience and education level, $F(1,25)=.371, p=.548$

Based on the findings, the study could not reject the null hypothesis and concluded that there was neither significant difference in teachers' mean scores on the policy guidelines contribution to parental involvement in decision making in ward schools in Rukwa region based on education level, school location and work experience nor significant combined effect of the three independent variables.

The findings imply that the participants had similar experience of the contribution of the policy guidelines to parental involvement in decision making in schools. They are consistent results and reliable as the independent variables had no strong influence on the scores. The policy guidelines performed more or less the same way in the ward schools on the aspect of making contribution to parental participation in deciding on major plans in the schools.

\section{Conclusions}

Based on the findings, the study drew various conclusions.

Firstly, the policy guidelines were less effective much as they did not improve parents' involvement to a large extent. Only a little was achieved in some schools. The approach to implementing the policy guidelines, among others, made them fail to adequately involve the parents in the schools. Besides not being all clear to school management and to parents, in some areas, they could impact change in the levels of parental involvement if they were professionally implemented. The few schools that did implement them effectively and made significant contribution to more parental involvement in the schools, prove this fact.

The study further concludes that parents were ready to monitor the implementation of the policy and could use appropriate means and relevant authorities.

Teachers' education level, work experience and school location had no significant influence on their scores on the effectiveness of the policy guidelines in relation to improving parental involvement or contributing to more involvement in the management of ward schools and the independent variables had no combined effect on the scores.

\section{Recommendations}

Based on the findings and conclusions of the study, the researcher made some recommendations. To begin with, the study recommends that education professionalism should be maintained in implementing the education policy. The policy planning and implementation process should anchor on participatory principle to ensure shared purpose and collective responsibility and efficacy of the stakeholders including parents with a view to enhancing effective implementation of the education policies. The government needs to revisit the approaches to implementation of the policy as the objectives were achieved at a low extent besides dividing students and parents.

The parents should be responsible for their children's education and actively take part in all education matters that concern them in the schools where their children learn. They should work with the communities around the schools to play their roles as per the policy.

The heads of schools should enhance participatory decision making to provide room for parents to play their part in the running of the institutions. They should be transparent, and invite parents to take part in schools plans so as to scale up their involvement in the schools. Proper and regular communication between schools and parents should be ensured to make parents support the institutions. They should focus on mobilizing parents to win their support as part of involving them in the administrative and management systems in the schools. More importantly, concerted efforts could be made to educate and mobilize parents to support the running of the schools for achieving the policy objectives.

\section{References}

i. Ary, D.; Jacobs, L.C.; and Sorensen, C.K. (2010). Introduction to Research. (8 $8^{\text {th }}$ Ed.) Wadsworth; CENGAGE Learning

ii. Bennaars, G. A. (1993). Ethics, Education and Development: An introductory text for students in colleges and universities. Nairobi: East African Educational Publishers

iii. Bernard, E.G. (2004). Perceived relevance of school boards in school improvement and leadership effectiveness in Musoma district council. (Masters Dissertation): UDSM

iv. Burilo, L.J. (2014). Community participation in quality education improvement in ward secondary schools in Temeke municipality. (Masters Dissertation): UDSM

v. Butsankom, A, Sirishuthi, C. and Lammana, P, (2016). The Development effectiveness management model for subdistrict secondary school, Education Research and Reviews, 11(19), 1790 - 1804. DOI: 10.5897/ERR2016.2849

vi. Cameron, J. and Dodd, W.A. (1970). Society, Schools and Progress in Tanzania

vii. Oxford: Pergamon Press

viii. Chawe, M. (2017, July 15). Serikali yakemea upotoshaji elimu bure [The government rebukes misrepresentation of free education], Habarileo, p.4

ix. Clatworthy, F. J. (1969). The Formulation of British colonial education policy, 1929-1961. Final Report. Michigan University

x. Creswell, J.W. (2009). Research Design: Qualitative, Quantitative, and Mixed Methods

xi. Approaches. ( $3^{\text {rd }}$ Ed). Los Angeles: SAGE Publications, Inc.

xii. Creswell, J.W. (2014). Research Design: Qualitative, Quantitative, and Mixed Methods Approaches. (4th Ed). Los Angeles: SAGE Publications, Ltd.

xiii. Datta, A. (1984). Education and Society:A Sociology of African Education, London: The Mcmillan Press Ltd 
xiv. Denise, C. D. (2013). An Investigation of African American Parents' Perception of School

xv. Leaders as it Relates to Parent Engagement and the African American Male Students.

xvi. Ed Dissertation, Fayetteville State University

xvii. Fanuel, G. (2015). Parents' involvement in promoting students' academic performance in secondary schools in Same District, Tanzania. (Masters Dissertation): Mwenge Catholic University (MWECAU)

xviii. Feuerstein, A. (2015). Parental trigger laws and the power of framing in educational politics. Education Policy Analysis Archives, 23(79), 1 - 3. Retrieved from:

xix. http://dx.doi.org/10.14507/epaa.v23.1992

xx. Focus, S. (2010). Internal efficiency of community secondary schools in Maswa district. (Masters Dissertation): UDSM

xxi. Hakielimu (2017). Impact of the implementation of fee-free education policy on basic education in Tanzania: A qualitative study. Research report: Da es Salaam

xxii. Hinzen, H. and Hundsdörfer, V. H. (1982). Education for Liberation and Development: The Tanzanian Experience. London: Evans and Brothers Limited. unesdoc.unesco.org /images/0003/000372/037278eo.pdf

xxiii. Ismail, B. (2017, January, 27). Wazazi, Walezi waweka ngumu mchango wa chakula shuleni [Parents, guardians resist contribution for food in schools]; Mwananchi News Paper, Local News, p.8

xxiv. Kabir, A. H. and Akter, F. (2014). Parental involvement in the secondary schools in Bangladesh: Challenges and the way forward. International Journal of whole schooling, $10(1), \quad 1 \quad-\quad 8$. https://files.eric.ed.gov/fulltext/EJ1030575.pdf

xxv. Kalolo, F.J. (2016). Craving for quality education in Tanzania: Dispelling the myths. Journal of Education Issues, 2(1), 57 - 69. DOI:10.5296/jei.v2i1. 8506

xxvi. Kapinga, O. (2016, December). Assessment of school facilities in the context of free basic education in Tanzania: A paper presented at the quality education conference at Seashells Hotel Millennium Tower, Dar es Salaam

xxvii. Khalfan, H. (2010). Constraints in managing community secondary schools in the Morogoro municipality, Tanzania. (Masters Dissertation): UDSM

xxviii. Kimambo, I.N. and Temu, A.J. eds. (1969). A History of Tanzania, Nairobi: East African Publishing House

xxix. Kuleana, Center for Children's Rights (1999). The state of education in Tanzania: Crisis and opportunity; Da es Salaam: Kuleana

xxx. Lawuo, Z. E. (1977). Education and change in a rural community: A study of colonial education and local response among the Chagga of Kilimanjaro between 1920 and 1945. (PhD Dissertation): UDSM

xxxi. Lesley, E. L. (2016). What parents still "do not" know about no child left behind and why it matters" Journal of Education Policy, 31(3), 343-361. DOI: 10.1080/02680939.2915.1094576

xxxii. Leos-Urbel, J, and Fehrer, K. (2016). We are one team: Examining community school

xxxiii. implementation strategies in Oakland, Education Sciences

xxxiv. Maendaenda, T. (2010). Causes and patterns of dropouts in community secondary schools: A case study of Korogwe town council, Republic of Tanzania. (Masters Dissertation): UDSM

xxxv. Magava, O.J. (2015). Constraints on the successful implementation of the universal and compulsory primary education policies in Tanzania, 1967 - 2013. (PhD Education Dissertation): UDSM

xxxvi. Mahmoud, S. (2018). Saudi parents' perceptions of the kind of help they offer to their primary school kids. English Language Teaching, 11(3), 102 - 112. DOI: 10.5539/elt.v11n3p102

xxxvii. Makwinya, N.M and Komba, S.C. (2014). Community - school partnership in Tanzania: The Role of parents' perceptions regarding communication and democracy in the partnership. Journal of Education; 2 (12), 1 - 14. https://www.researchgate.net/publication/270583551

xxxviii. Masue, O.S. (2014). Empowerment of school committees and parents in Tanzania: Delineating existence of opportunity, its use and impact on school decisions. (PhD Dissertation): University of Bergen. Retrieved from http://citeseerx.ist.psu.edu/viewdoc/download?doi=10.1.1.841.2866\&rep=rep1\&type=pdf

xxxix. Matshe, P.F.A. (2014).Challenges of parental Involvement in rural public schools in Ngaka Modiri Moleme District of North West Province (South Africa). International Journal of Humanities Social Sciences and Education (IJHSSE),1(6), 93-103 (Online) www.arcjournals.

xl. Mbaraka, H. (2015). An Assessment of parents' degree of financial contribution for secondary education in Tanzania: A comparative study between community and private secondary schools in Ilala municipality. (Masters Dissertation): UDSM

xli. Mbelle, A.V.Y. (2008). The impact of reforms on the quality of primary education in Tanzania. Research report. Dar es Salaam: REPOA. Retrieved from: https://www.africaportal.org/publications/

xlii. Mbugua, F. and Rarieya, J.F.A. (2014). Collaborative Strategic Planning: Myth or Reality? Educational Management Administration \& Leadership, 42(1), 99-111. DOI: 10.1177/1741143213499258

xliii. Mhegera, I.E. (2011). Sumbawanga ward secondary schools report. Retrieved from mhegeraelias.blogspot.com/2011/12/Sumbawanga-ward-secondary-schools-report.html Retrieved on $22 / 06 / 2017$

xliv. Mshani, G. (2015). Poverty indicators affecting academic performance in Tanzania secondary schools at Nkasi district, (Masters Dissertation): OUT

xlv. Mtolea, H.H. (2007). Community involvement in staff management practices. A Study of selected community secondary schools in the Coast Region in Tanzania. (Masters Dissertation): UDSM 
xlvi. Mualuko, N.J and Limukii, K.E. (2012). The free education policy in Kenya: A critique; International Journal of Education Administration and Policy Studies, 4 (1), 1-5. DOI: 10.5897/IJAPS10.031

xlvii. Mujora, J. (2014). Effectiveness of school boards in improving secondary school governance in Kinondoni municipality, (Masters Dissertation): UDSM

xlviii. Munishi, M.P. (2014). The assessment of heads of schools' managerial competency after attending in-service training in coast region, (Masters Dissertation): UDSM

xlix. Mwingira, A.C. and Pratt, S. (1967). The Process of Educational Planning in Tanzania Paris: UNESCO. unsedoc.unesco.org/images/0007/000768/076893eo.pdf

l. Nettelbeck, D. (1974). A History of Arusha School, Tanzania. (Masters Dissertation): University of Adelaide. Retrieved from https://ntz.info/docs/history_of_arusha_school.pdf

li. Ngalawa,A.; Simmt, E. and Glanfield, F. (2015). Exploring the emergence of community support for school and encouragement of innovation for improving rural school performance: Lessons learned at Kitamburo in Tanzania. Global Education Review, 2 (4). 101 - 119. https://files.eric.ed.gov/fulltext/EJ1080909.pdf

lii. Njoroge, R. J and Bennaars, G.A. (1986). Philosophy and Education in Africa. An Introductory Text for Students of Education, Nairobi: Transafrica Press

liii. Nyandwi, D.M. (2014). Determinants of poor academic performance of secondary school students in Sumbawanga district, Tanzania, (Maters Dissertation): Sokoine University of Agriculture (SUA)

liv. Nyerere, J. K. (1967). Elimu ya Kujitegemea, Dar es Salaam: National Printing Company Limited

lv. Omari, I. M. (1968). The role of T.A.P.A. (Tanganyika African Parents Association) as an education institute; Mbioni: The monthly journal of KIVUKONI COLLEGE, 4(12), 3 - 25

lvi. Orotho, J. A. and Adan, M.A. (2015). Constraints of implementing free secondary education in Mandera West Sub County Mandera County, Kenya. Journal of Education and Practice, 6(9), 102- 110. https://files.eric.ed.gov/fulltext/EJ1082462.pdf

lvii. Owino, F.R. (2000). Recreation of Africa through language, culture and education. In G.P.

lviii. Oyeniran, R. (2017). Basic education in Ivory Coast: From education for all to compulsory education; Challenges and perspectives. Journal of Education and Learning; 6(2), 283 - 29. DOI: 10.5539/jel.v6n2p283

lix. Parkay, F.W.; Anctil, E.G and Hass, G. (2010) Curriculum Leadership, Boston: Pearson Education, Inc

lx. Punch, K.F. (2009). Introduction to Research Methods in Education. London: SAGE Publications Ltd

lxi. Rajabu, H. (2011). The role of parents' associations in improving the academic performance of public secondary schools in Tanzania. (Masters Dissertation): UDSM

lxii. Rapp, N. and Duncan, H. (2012). Multi-Dimensional parental involvement in schools: A Principal's guide" International Journal of Educational Leadership Preparation, vol. $7(1), \quad 1 \quad-\quad 14$. https://files.eric.ed.gov/fulltext/EJ971515.pdf

lxiii. Redempta, M. and Mwebi, R. B. (2016) Perceptions of parents on the practice of private tuition

lxiv. in public learning institutions in Kenya, Journal of Education and Practice, 7(4),122-

lxv. 128

lxvi. Salema, V. (2009). An Evaluation of the implementation of secondary school education

lxvii. development plan (SEDP)in government - community secondary schools in Rombo

lxviii. District, Kilimanjaro - Tanzania. M.Ed. Dissertation: Catholic University of Eastern

lxix. Africa (CUEA)

lxx. Scott, J. (1925). Report by His Majesty's Government on the Administration under man date of Tanganyika Territory for the year 1924. Report of Mandate Powers.c. 452 (d). M. 166 (d). 1925. VI. Retrieved from: https://biblioarchive.unog.ch/Dateien/CouncilMSD/C-452\%28d\%29-M-166\%28d\%29-1925-VI_EN.pdf

lxxi. Seni, A.J. (2013). History and Development of Education in East Africa. LAP LAMBERT Academic Publishing

lxxii. Shun-wing Ng \& Wai. K. G. Y. (2015). The Micro-politics of parental involvement in school education in Hong Kong: Ethnocentrism, utilitarianism or policy rhetoric Educational Review, 67(2), 253-271. D0I: $10.1080 / 00131911.2013 .868786$

lxxiii. Siyame, P. (2016, January, 15). Rukwa RC orders all parents who fail to send their children to school traced. Daily news, Local news, p.2

lxxiv. Siyame, P. (2016, January, 25).Parents refuse to pay for meals. Daily news, p.2

lxxv. Siyame, P. (2016, October 11). Parents with truant children on the run in Rukwa, Daily news, Home news, p.2

lxxvi. Siyame, P. (2016, December 1). 10,800 selected to join form one. Habarileo, p.2

lxxvii. Tarimo, E.C.J. (1996). Education development in mainland Tanzania, A tripartite responsibility, 1961 - 1994. (Master Dissertation): UDSM

lxxviii. Telli, G. (20140. Bridging the gap of Tanzanian education leadership between theoretical perspectives and practical approach as a means to bring changes in education and alleviate poverty. Mwenge Journal of Academic Studies 2(1), $38-57$

lxxix. THAKERS LIMITED (1965, February 1). Bidii ya TAPA (TAPA's effort), Ngurumo, p.2

lxxx. Tricia, F.B.; Paul, C. and Lewis, W.D (2011). Parental involvement in public school governance: The United States and South Africa, Journal of School Public Relations, 32(4), 325-348

lxxxi. URT (1978). Education Act No 25. Dar es Salaam: Ministry of Education and Vocational Training (MoEVT)

lxxxii. URT (1995). Education and Training Policy. Dar es Salaam: MoEVT

lxxxiii. URT (2001). Education status country report, Dar es Salaa. MoEC 
lxxxiv. URT (2004). Education Sector Development Programme: Secondary Education Development Programme (SEDP). Dar es Salaam: MoEVT

lxxxv. URT (2014). Basic Education Statistics in Tanzania (BEST), Dar es Salaam: MoEVT

lxxxvi. URT (2014). Education and Training Policy, Dar es Salaam: MoEVT

lxxxvii. URT (2015). Secondary School Management Toolkit (SSMT), Practical Guide for Heads of Schools: MoEVT

lxxxviii. URT (2015). Waraka elimu namba 6 wa mwaka 2015 kuhusu utekelezaji wa elimu msingi bila malipo [Education circular number 6 of 2015 on implementing fees free basic education Dar es salaam: MoEVT

lxxxix. URT (2016). Basic Education Statistics in Tanzania (BEST), Dar es Salaam: MoEST

xc. URT (2016). Waraka wa elimu namba 3 wa mwaka 2016 kuhusu utekelezaji wa elimumsingi bila malipo [Education circular number 3 of 2016 on implementing fees free basic education].Ministry of Education, Science and Technology (MoEST)

xci. URT (2016, February 29). Utaratibu wa utoajiwa wa vibali vya kuchangia kwa hiari mahitaji kwa ajili ya kutatua kero zilizopo shuleni [Procedure for granting permits for voluntary contributions for allaying challenges in schools]. Dodoma: Tawala za Mikoa na Serikali za Mitaa (TAMISEMI)

xcii. Yassin, I. (2017, January 31). A Teacher caned for punishing a student. Tanzania Daima, News, p. 2

xciii. Zahara, A. (2014). Factors hindering effective parental involvement in children's schooling in public primary schools in Kinondoni municipality, Tanzania. (Masters Dissertation): UDSM 